\title{
p-TsOH Catalyzed synthesis of 2-arylsubstituted benzimidazoles
}

\author{
Han Xiangming, ${ }^{\mathrm{a}, \mathrm{b}}$ Ma Huiqiang, a and Wang Yulu *a \\ ${ }^{a}$ College of Chemical and Environmental Science, Henan Normal University, Xinxiang, 453007, \\ Henan, P. R. China \\ ${ }^{b}$ Department of Chemisrty and Environmental Engineering, Pingyuan University, Xinxiang, \\ 453003, Henan, P. R. China \\ E-mail:wyl@henannu.edu.cn
}

\begin{abstract}
$p$-TsOH $(20 \mathrm{~mol} \%)$ was used to be a catalyst for the synthesis of 2-arylsubstituted benzimidazoles efficiently. Simple and convenient procedure, easy purification and shorter reaction time are the advantageous features of this method.
\end{abstract}

Keywords: Benzimidazole, synthesis, $p$-TsOH, arylaldehyde, $o$-phenylenediamine

\section{Introduction}

Benzimidazole derivatives exhibit significant activity against several viruses such as HIV, ${ }^{1}$ herpes (HSV-1), ${ }^{2} \mathrm{RNA}^{3}{ }^{3}$ influenza, ${ }^{4 a}$ and human cytomegalovirus (HCMV) ${ }^{1}$. The widespread interest in benzimidazole-containing structures has promoted extensive studies for their synthesis. While many strategies are available for benzimidazole synthesis, ${ }^{7-16}$ there are two general methods for the synthesis of 2-substituted benzimidazoles. One is the coupling of phenylenediamines and carboxylic acids ${ }^{4 \mathrm{~b}}$ or their derivatives (nitriles, imidates, or orthoesters), ${ }^{5}$ which often requires strong acidic conditions, and sometimes combines with very high temperatures or microwave irradiation. ${ }^{6}$ The other way involves a two-step procedure that includes the oxidative cyclo-dehydrogenation of Schiff bases, which are often generated from the condensation of phenylenediamines and aldehydes. Various oxidative and catalytic reagents such as sulfamic acid, ${ }^{7} \mathrm{I}_{2},{ }^{8} \mathrm{DDQ},{ }^{9}$ Air, ${ }^{10}$ Oxone, ${ }^{11} \mathrm{FeCl}_{3} \cdot 6 \mathrm{H}_{2} \mathrm{O},{ }^{12} \mathrm{In}(\mathrm{OTf})_{3},{ }^{13} \mathrm{Yb}(\mathrm{OTf})_{3}{ }^{14}$ $\mathrm{Sc}(\mathrm{OTf})_{3},{ }^{15} \mathrm{KHSO}_{4},{ }^{16} \mathrm{IL}^{17}{ }^{17}$ have been employed. Because of the availability of a vast number of aldehydes, the condensation of phenylenediamines and aldehydes has been extensively used. While many published methods are effective, some of these methods suffer from one or more disadvantages such as high reaction temperature, prolonged reaction time, and toxic solvents etc. Therefore, the discovery of mild and practicable routes for synthesis of 2-substituted benzimidazoles continues to attract the attention of researchers. 
In recent times, we have shown $\mathrm{KHSO}_{4}{ }^{16}$ and $\mathrm{IL}^{17}$ can be used as promoters and catalysts for the synthesis of benzimidazoles. So we tried to synthesize benzimidazoles using an organocatalyst. In this paper, $p$-TsOH ${ }^{18}$ was used for the synthesis of 2-arylsubstituted benzimidazoles by the condensation of aryl aldehyde with $o$-phenylenediamine (Scheme 1).

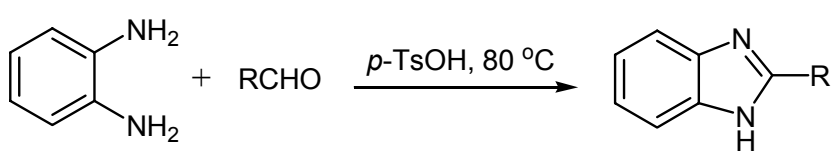

\section{Scheme 1}

In order to establish the optimum condition for this reaction, various ratios of $p$-TsOH were examined. Using $o$-phenylenediamine and $p$-chlorobenzaldehyde as a model, $p$-TsOH was added in various ratios in DMF at $80^{\circ} \mathrm{C}$. As shown in Table 1, very little of the desired products was obtained in the absence of $p$-TsOH and the best yields were obtained with $20 \% \mathrm{p}-\mathrm{TsOH}$.

Next the effect of solvent was examined. As shown in Table 2, different solvents can result in different yields. Clearly DMF stands out as the solvent of choice, with its fast conversion, high yield and low toxicity.

To test the general scope and versatility of this procedure in the synthesis of a variety of 2substituted benzimidazole, we examined a number of differently substituted arylaldehydes. We were pleased to find that moderate to high yields were obtained in the condensation of $o$ phenylenediamine with aldehydes. As Table 3 shows that aryl aldehydes bearing both electrondonating and electron-withdrawing substituents gave the desired benzimidazoles in good yields. Heteroaryl aldehyde (Entry 8) and $\alpha, \beta$-unsaturated cinnamicaldehyde (Entry 9) also gave acceptable yields. Whereas little product was obtained when aliphatic aldehydes were used.

Table 1. Various ratios of $p$-TsOH for the synthesis of 2-(4-chlorophenyl)benzimidazole

\begin{tabular}{llll}
\hline Entry & $p$-TsOH $(\mathrm{mol} \%)$ & Time $(\mathrm{min})$ & Yield $^{\mathrm{a}}$ \\
\hline 1 & 0 & 10 & trace \\
2 & 10 & 10 & 75 \\
3 & 20 & 10 & 82 \\
4 & 40 & 10 & 81 \\
5 & 50 & 10 & 81 \\
6 & 100 & 10 & 81 \\
\hline
\end{tabular}

${ }^{a}$ All yields refer to isolated product.

The possible mechanism is shown below. 


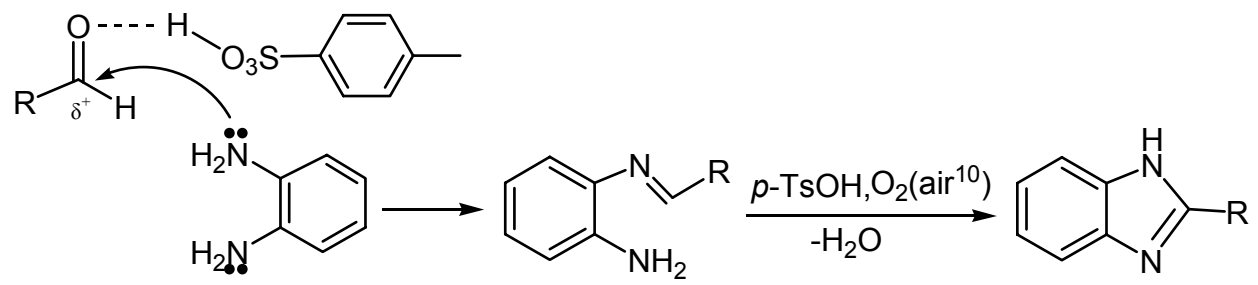

Table 2. Effect of solvent in condensation of $o$-phenylenediamine with 4- chlorobenzaldehyde

\begin{tabular}{lcll}
\hline Entry & Solvent & Conditions $^{\text {b }}$ & Yield $^{\mathrm{a}}(\%)$ \\
\hline 1 & $\mathrm{CH}_{2} \mathrm{Cl}_{2}$ & reflux & 17 \\
2 & $\mathrm{THF}$ & reflux & 30 \\
3 & $\mathrm{CH}_{3} \mathrm{OH}$ & reflux & 57 \\
4 & $\mathrm{CH}_{3} \mathrm{CH}_{2} \mathrm{OH}$ & reflux & 63 \\
5 & $\mathrm{H}_{2} \mathrm{O}$ & $80^{\circ} \mathrm{C}$ & 53 \\
6 & $\mathrm{DMSO}$ & $80^{\circ} \mathrm{C}$ & 79 \\
7 & $\mathrm{DMF}$ & $80^{\circ} \mathrm{C}$ & 82 \\
\hline
\end{tabular}

${ }^{\mathrm{a}}$ All yields refer to isolated product. ${ }^{\mathrm{b}}$ Reaction time: $10 \mathrm{~min}$.

Table 3. Synthesis of benzimidazoles catalyzed by $p-\mathrm{TsOH}$

\begin{tabular}{llll}
\hline Entry & $\mathrm{R}$ & Time $(\mathrm{min})$ & Yield $^{\mathrm{a}}(\%)$ \\
\hline 1 & $\mathrm{C}_{6} \mathrm{H}_{5}$ & 10 & 85 \\
2 & $4-\mathrm{ClC}_{6} \mathrm{H}_{4}$ & 10 & 82 \\
3 & $4-\mathrm{NO}_{2} \mathrm{C}_{6} \mathrm{H}_{4}$ & 15 & 81 \\
4 & $3-\mathrm{NO}_{2} \mathrm{C}_{6} \mathrm{H}_{4}$ & 15 & 80 \\
5 & $2-\mathrm{ClC}_{6} \mathrm{H}_{4}$ & 15 & 80 \\
6 & $4-\mathrm{CH}_{3} \mathrm{C}_{6} \mathrm{H}_{4}$ & 15 & 80 \\
7 & $4-\mathrm{CH}_{3} \mathrm{OC}_{6} \mathrm{H}_{4}$ & 15 & 81 \\
8 & $2-$ furyl $_{9}$ & 10 & 70 \\
9 & $\mathrm{C}_{6} \mathrm{H}_{5} \mathrm{CH}_{=} \mathrm{CH}$ & 10 & 60 \\
10 & $\mathrm{CH}_{3}\left(\mathrm{CH}_{2}\right)_{5}$ & 60 & trace \\
11 & $\mathrm{CH}_{3} \mathrm{CH}_{2} \mathrm{CH}_{2}$ & 60 & trace \\
12 & $\mathrm{CH}_{3} \mathrm{CH}_{2}$ & 60 & trace \\
\hline
\end{tabular}

${ }^{a}$ All yields refer to isolated product, characterized by melting points, ${ }^{1} \mathrm{H}$ NMR.

In conclusion, we have developed a simple, one-pot synthesis of 2-arylsubstituted benzimidazoles by the condensation of $o$-phenylenediamine with arylaldehyde catalyzed by $p$ $\mathrm{TsOH}$. Simple and convenient procedure, easy purification and shorter reaction time are the advantageous features of this method 


\section{Experimental Section}

General Procedures. All melting points were determined on a Kofler micro melting point apparatus and were uncorrected. IR spectra were recorded on a SP3-300 spectrophotometer using $\mathrm{KBr}$ discs. ${ }^{1} \mathrm{H}$ NMR spectra were measured on a Bruker DPX-400M spectrophotometer using TMS as internal standard and $\mathrm{CD}_{3} \mathrm{SOCD}_{3}$ as solvent.

\section{Typical procedure for synthesis of benzimidazoles}

Aldehyde $(0.5 \mathrm{mmol})$ and $o$-phenylenediamine $(0.5 \mathrm{mmol})$ were thoroughly mixed in DMF ( 2 $\mathrm{mL})$, then $p$-TsOH $(0.1 \mathrm{mmol})$ was added, and the solution heated and stirred at $80{ }^{\circ} \mathrm{C}$ for appropriate time ( monitored by TLC). When the reaction was finished, the solution was cooled to r.t.. The reaction mixture was added dropwise with vigorous stirring into a mixture of $\mathrm{Na}_{2} \mathrm{CO}_{3}$ $(0.1 \mathrm{mmol})$ and $\mathrm{H}_{2} \mathrm{O}(20 \mathrm{~mL})$. In cases where the product precipitated as a free flowing solid, it was collected by filtration, washed with $\mathrm{H}_{2} \mathrm{O}$ and dried. In cases where gummy material precipitated the product was extracted into EtOAc, the organic phace was washed with $\mathrm{H}_{2} \mathrm{O}$, brine and dried $\left(\mathrm{Na}_{2} \mathrm{SO}_{4}\right)$. Evaporation of solvent gave the crude product, which was purified by column chromatography over silica gel (cyclohexane:ethyl acetate, 3:1 ) to afford the corresponding benzimidazole.

All of the compounds are known compounds. They were identified from their ${ }^{1} \mathrm{H}$ NMR spectroscopic data and by comparing their mps with those reported in the literature (references cited). 1: mp 287-288 ${ }^{\circ} \mathrm{C}$ (lit., ${ }^{19 a} 292{ }^{\circ} \mathrm{C}$ ); 2: mp $288-291{ }^{\circ} \mathrm{C}$ (lit., ${ }^{19 a} 294{ }^{\circ} \mathrm{C}$ ); 3: mp 308-310 ${ }^{\circ} \mathrm{C}$ (lit., ${ }^{19 \mathrm{a}} 316^{\circ} \mathrm{C}$ ); 4: mp 200-202 ${ }^{\circ} \mathrm{C}$ (lit., ${ }^{19 \mathrm{~b}} 204-206{ }^{\circ} \mathrm{C}$ ); 5: mp 230-231 ${ }^{\circ} \mathrm{C}$ (lit., ${ }^{19 \mathrm{a}} 234{ }^{\circ} \mathrm{C}$ ); 6: mp 261-263 ${ }^{\circ} \mathrm{C}$ (lit., ${ }^{19 \mathrm{a}} 270{ }^{\circ} \mathrm{C}$ ); 7: mp 228-230 ${ }^{\circ} \mathrm{C}$ (lit., ${ }^{19 a} 226{ }^{\circ} \mathrm{C}$ ); 8: mp 284-286 ${ }^{\circ} \mathrm{C}$ (lit., ${ }^{19 \mathrm{a}} 288$ $\left.{ }^{\circ} \mathrm{C}\right)$; 9: mp 199-201 ${ }^{\circ} \mathrm{C}$ (lit., ${ }^{19 \mathrm{a}} 203-205^{\circ} \mathrm{C}$ );

\section{References}

1. Porcari, A. R.; Devivar, R. V.; Kucera, L. S.; Drach, J. C. ; Townsend, L. B. J. Med. Chem. 1998, 41, 1252. (b) Roth, T.; Morningstar, M. L.; Boyer, P. L.; Hughes, S. H.; Buckheitjr, R. W.; Michejda, C. J. J. Med. Chem. 1997, 40, 4199.

2. Migawa, M. T.; Girardet, J. L.; Walker, J. A.; Koszalka, G. W.; Chamberlain, S. D.; Drach, J. C., Townsend, L. B. J. Med. Chem. 1998, 41, 1242.

3. Tamm, I.; Sehgal, P. B. Adv. Virus Res. 1978, 22, 187.

4. Tamm, I. Science 1957, 126, 1235. (b) Hisano, T.; Ichikawa, M.; Tsumoto, K.; Tasaki, M. Chem. Pharm. Bull. 1982, 30, 2996.

5. Czarny, A.; Wilson, W. D.; Boykin, D. W. J. Heterocycl. Chem. 1996, 33, 1393. (b) Tidwell, R. R.; Geratz, J. D.; Dann, O.; Volz, G.; Zeh, D.; Loewe, H. J. Med. Chem. 1978, 21,613 
6. Reddy, G. V.; Rao, V. V. V. N. S. R.; Narsaiah, B.; Rao, P. S. Synth. Commun. 2002, 32, 2467. (b) Perumal, S.; Mariappan, S.; Selvaraj, S. Arkivoc 2004, 8, 46. (c) Rao, A.; Chimirri, A.; Ferro, S.; Monforte, A. M.; Monforte, P.; Zappalà, M. Arkivoc 2004, 5, 147.

7. Chakrabarty, M.; Karmakar, S.; Mukherji, A.; Arima, S.; Harigaya, Y. Heterocycles 2006, 68, 967.

8. Gogoi, P.; Konwar, D. Tetrahedron Lett. 2006, 47, 79.

9. Lee, K. J.; Janda, K. D. Can. J. Chem. 2001, 79, 1556.

10. Lin, S.; Yang, L. Tetrahedron Lett. 2005, 46, 4315.

11. Beaulieu, P. L.; Hache, B., Von Moos, E. Synthesis 2003, 1683.

12. Singh, M. P; Sasmal, S.; Lu, W.; Chatterjee, M. N. Synthesis 2000, 1380.

13. Trivedi, R.; De, S. K.; Gibbs, R. A. J. Mol. Cat. A: Chem. 2005, 245 , 8.

14. Massimo, C.; Francesco, E.; Francesca, M. Synlett 2004, 1832.

15. (a) Itoh, T.; Nagata, K.; Ishikawa, H., Ohsawa, A. Heterocycles 2004, 63, 2769. (b) Nagata, K.; Itoh, T.; Ishikawa, H., Ohsawa,A. Heterocycles 2003, 61, 93.

16. Ma, H. Q.; Wang, Y. L.; Wang J. Y. Heterocycles 2006, 68, 1669.

17. Ma, H. Q.; Wang, Y. L.; Li, J. P.; Wang, J. Y Heterocycles 2007, 71, 135.

18. Bonardi, L.; Ulrich, G.; Ziessel, R. Synlett 2006, 450

19. Ben-Alloum, A.; Bougrin, K.; Soufiaoui, M. Tetrahedron Lett. 2003, 44, 5935. (b) DeLuca, M. R.; Kerwin, S. M. Tetrahedron 1997, 53, 457. (c) Dubey, P. K.; Kumar, R.; kumar, C. R.; Grossert, J. S.; Hooper, D. L. Synth. Commun. 2001, 31, 3439. 